\title{
QUALITY OF IMPLEMENTATION OF PUBLIC SERVICES IN THE PUBLIC SERVICE MALL (MPP) IN SUMEDANG DISTRICT
}

\begin{abstract}
Ade Irawan
Universitas Pasundan, Bandung, West Java, Indonesia

adeirawan@unpas.ac.id

Abstract

This study is to examine Describe and analyze the quality of the implementation of public services by the district government in public services through the Public Service Mall (MPP) in the Sumedang patent district. Seeing the supporting factors and servants in the process of public service that refers to KememPan number 31 of 2019 there are still not many maximums from the start of the regent's regulations that have not yet come out even though the service has begun to run, this study will analyze how public services should be carried out in the process of implementing the pub service system lik through the Mall Public Services (MPP) in Sumedang Regency. The method used in the activity is a descriptive method through a qualitative approach. With this method and approach, it is expected to be able to describe various problems in their entirety and comprehensively, so that the results of the problem analysis can be used as a basis for understanding phenomena and giving birth to a concept of the quality of public service delivery in Sumedang Regency .
\end{abstract}

Keyword : Services Public, Local Government Sumedang.

\section{Introduction}

Public services according to Harbani Pasolong (2007:128), are : Every activity that is carried out by the government against a number of human beings who have every activity that is beneficial in a group or entity, and offers a satisfaction even though the results are not dependent on a product in the physical. But the problem Services Public is not always evenly distributed to the City/Country that exits in Indonesia, for the researchers tried to examine the study of case analysis comparison service public between the District Sumedang.

Government District Sumedang it self always trying increase service public to answer the challenge of making the District Sumedang promote the services public in order towards World Cities that during this echoed. It was also seen since the operation of services of Integrated One
Door (PTSP) DI District Sumedang which manage various kinds of services to facilitate community especially society eg start of recording E-ID card, payment taps, until the payment of tax vehicle Bermo tor. Will but servicing the public that there is in the District Sumedang still needs to be improved, still many yang need to be repaired. Seeing the situation that exist in the District Sumedang, although the trend was already nice there is a commitment stronger than the government and stakeholders related to improve the services the public but its achievement has not been maximum. By because it is, needs to their research regarding policy in the Government District Sumedang. However, in relation to the nature of the goods of private and goods public pure, then the government is the only party that is obliged to provide goods publicly pure, especially the stuff the public who called rules or rules (policies public). 
Goods publicly pure that such rules are not onc e and not be handed over their provision to private, because if things were do ne then in the rules that will be attached to the interests of the private who make the rules, so that the rules be filled with vested interests and be not unjust (unfair rule). So the role of government that will remain attached throug hout its existence is as a provider of goods public pure are called rules.

Accordingto Kristian Widya Wicaksono (2006 : 9), at the level of general, when bureaucracies do service the public by either the bureaucracy that is able to show some indication of behavior:

1) Process the job as a stable and viable ;

2) Treating individuals who relate to him in a fair and impartial ;

3) Employ and retain employees based on pr ofessional qualifications and orientation $\mathrm{t}$ owards program success ;

4) Promote staff based system meriet and th e results of the work well which can be proved ;

5) Perform maintenance of the achievements that have been achieved so that it can immediately rise when faced with adversity.

While

the purpose

of serving the government bureaucracy is, as $\mathrm{f}$ ollows: essence of responsibility accountable gov ernment.
1) a number of services as the
2) Advancing
the interests of specific economic sectors, such as agriculture, labor or certain segments of private busin ess.
3) Make regulations on various private activ ities.
4) Distributed a number of benefits such as income, rights, medical care and others.

\section{Method}

This research uses a qualitative approach. Approach qualitative to obtain information which describe patterns of specific, for example, the pattern of relations of power (power) and the authority in the relationship between the implementation of regional autonomy government district/city, with the mechanism of the use of local budgets. In general, according to Patton (1990), qualitative methods allow researchers to conduct studies of specific issues in depth and in detail. The use approach qualitative as well adapted to the characteristics that exist that the researcher is directly involved in the location of the research through observation did not involved (non participant observation).

\section{Result and Discussion}

Widodo (2005: 163), stated: The current condition of the community has occurred a very dynamic development, the level of community life that is getting better, is an indication experienced by the community. This means that people are increasingly aware of their rights and obligations as citizens in living as a society, nation and state. The public is increasingly brave to submit demands, desires and aspirations to the government. The public is increasingly critical and increasingly brave to exercise control over what is done by the government. The condition of society as described above, public bureaucracy must be able to provide public services that are more professional, effective, simple, transparent, open, timely, responsive and adaptive as well as being able to build human qualities in the sense of increasing the capacity of individuals and society to actively determine the period of time. front of him himself. The direction of the development of human quality is to empower human capacity in the sense of creating conditions that allow each member of the community to develop their abilities and creativity to manage and determine their own future.

Professional public services are at least based on accountability, and responsibility from service providers (government officials) through strengthening service institutions by prioritizing effectiveness in achieving what are the goals and objectives, simple in the procedures and procedures for services that are 
carried out easily, quickly, precisely, not convoluted, easily understood and easily implemented by people who ask for services, the need for clarity and certainty (transparent) regarding certainty regarding service requirements, both technical and administrative requirements, work units and or officials who are authorized and responsible in providing services, details of service fees / tariffs and procedures for payment, as well as service completion times. Likewise, quality public services require openness which implies procedures / procedures for requirements, work units / officials in charge of service providers, time of completion, details of time / rates and other matters relating to the service process must be informed openly so that they are easily known and understood by the community, both requested and unsolicited, efficiency relates to the achievement of service targets while taking into account the integration of requirements with related service products, prevention of repetition of fulfillment of requirements, in terms of the relevant community service process requiring the completion of the requirements of the work unit / other relevant government agencies, the timeliness of the implementation of community services can be resolved within a predetermined period of time, responsive which is more directed to responsiveness and quickly responds to what is the problem, needs and aspirations the community served or adaptive, quickly adjusts to the demands, desires and aspirations of the people served who are always experiencing growth and development.

The development of today's world have berjaan so fast, technology has made the boundaries between informas $i$ and human needs of increasingly close. Speed and accuracy are also needed in the process of interaction between government and citizens, but unfortunately the high mobility of citizens is not matched by the accuracy and also the speed of the government in terms of service especially services to the public. Citizens have the right to get quality public services from the state (bureaucracy). Citizens also have the right to get protection of their rights, to hear their voices, as well as to respect their values and preferences. Thus, citizens have the right to judge, reject and prosecute anyone who ririskiky a politically responsible for the provider's public services. This concept is referred to as The New Public Service (NPS ) which was developed by Janet V. Denhardt and Robert B. Denhardt in 2003. The performance of public services can be improved if there is an "exit" and "voice" mechanism. The mechanism of "exit" fallow RTI that if the public service is not qualified consumer must me have the opportunity to choose the providers of other public services $y$ ang likes. While the mechanism of "voice " means the opportunity to express dissatisfaction with the agency penyelengga ra public service. This New Public Service Approach is in line with the "Exit" and "Voice" Theories_which was first developed by Albert Hirschman . Indonesia since 2009 has had legislation in itself as a standard for the of service to the community, then on July 18, 2009 Indonesia ratified Law No. 25 of 2009 on Public Service. According to the Act, public services are activities or a series of activities in the context of meeting the needs of service providers in accordance with the laws and regulations for each.

3.1 The Role of Leaders in Public Servants Leadership play an important role in the operation of the organization, institution, or nation. Leadership is often described as an attempt to influence and set an example to followers in achieving institutional goals (Chemers, 1997). The quality of the institution he leads is greatly influenced by the leadership of the leader himself. The paradigm shift in the meaning of leadership starts from the view of leaders as individuals in formal, rigid, and transactional characters. Today, 'Servant Leadership' appears and emphasizes that leaders are servants to others. In modern science, the leadership model is conceived by Robert K Greenleaf, known as "The Servant as Leader " and not "The Leader as Servant" (Smith, 2005). 
Serving leadership is the idea of leadership that focuses on serving the public, so that the leadership model is more likely to meet the needs and put the interests of the community. Some argue that such a model works with the application of spiritual principles. In the application of servant leadership, the relationship between leaders and followers is only to serve the interests of others. They are responsible for making other people feel comfortable, happy, and happy when interacting. Because it is universal and very easily accepted, servant leadership can be applied in all fields of institutions, including public sector organizations. Spears (1996) believes that Servant Leadership is a model that places 'serving others' as the top priority. Servant leadership has the following framework. First, it emphasizes improving services to others. The leader positions himself as a servant in his interactions with followers. Initially, the legitimacy of a leader is built not through the exercise of their great strength, but from the desire to help others. Thus, that fact is the key in building a leader's victory (Greenleaf, 1970). Second, a holistic approach to work. Greenleaf (1996) has the term "Work exists for that person as well as the person exists for the job" which can be interpreted as a person who is more active in the work environment, so the work will also be sustainable. This term criticizes the individualist theory that a person must be himself without having to interact with the organization and the social environment as a whole. Third, promote social sensitivity. Along with the rapid growth of the modern social environment, this results in erosion of the meaning of 'social'. In the perspective of the Servant Leader, he is required to provide social services. Pure service in a person does not come from a group or community.

Thus, the leader will determine the success of an organization that has high social sensitivity (Greenleaf , 1970). Fourth, divide authority in decision making. Opening opportunities for followers to participate and give more authority to their followers, serving leaders can create organizational effectiveness and employee motivation. Russell (2001) argues that if a leader wants to empower his followers, it is necessary to distribute authority, not fight it. As such, Servant Leadership is often described as an 'inverted pyramid' from the 'classical organizational pyramid' theory, by placing followers, clients, and stakeholders at the top and leaders at the bottom. It leads Servant Leadership as a flexible model in its application in an organization (Lee \& Zemke, 1993; Biberman \& Whitty, 1997). Many studies conducted by organizational behavior experts confirm ten characters as important characters that must be possessed by a servant leader (Joseph \& Winston, 2005), although many others have noted other important characters. Russell and Winston (2002)

propose at least 20 characters that must be possessed by serving leaders. While Greenleaf (1970) the idea of Servant Leadership analyzed

by Russell \& Stone (2002) identifies ten leading leadership characters, namely: listening, empathy, healing, awareness, persuasion, conceptualization, foresight, stewardship, commitment to people growth, and build community. At present, the public sector is under pressure to improve services and be able to work with other sectors to be more effective and efficient.

\subsection{The Role of Government in Public Services \\ According \\ to} WidodosecaThoha ra theoretically there are at least three major functions to be performed by the government regardless of the level, which is a function waiter masyar AKAT ( public service function), the function of development (development fu nction) and protection functions ( protection function). The government does not have to play a role as a monopolist in the implementation of all these functions. Bagia $\mathrm{n}$ of this function bias into the field of implementation tasks may be delegated to piha $\mathrm{k}$ privately or by using the pattern of the partnership (partnership), between the government and the private sector to menga dakannya. Patterns of 
cooperation between government and private sector in membe offered are a variety of services to the community is consistent with the

idea rein venting government that in developed Osborne and Gaebler.

The government is the only party that is obliged to provide pure public goods in relation to the nature of private goods and pure public goods, especially public goods called rules or rules (public policy). Purely public goods in the form of the regulation have never been and may not be surrendered to private provision in the regulation. Raises the interests of private which makes the rules, so as to set an be filled with a vested interest and be unfair (unfair rule). The role of the government that will remain inherent throughout its existence is as a provider of pure public goods called rules._In the book Delivering Quality Services of coral and Zeithaml, Valarie A. et.al, 1990, which discusses how the response and expectations

of the customer community to the services they receive, both in the form of goods and services. According to Valarie the things that need attention are :

a) Determine the public services provided, what are the kinds;

b) Treat service users, as customers ;

c) Trying to satisfy the user service, in accordance with what they want;

d) Looking for the best and highest quality service delivery method;

e) Providing ways, if the service user has no other choice.

An assessment of service quality cannot be separated from the ability of employees to provide services and the provision of physical facilities. This is consistent with the

theory"The triangle of balance in service qualit $y$ : from Morgan and Murgatroy $\mathrm{d}$, that needs to be maintained a balance of the three components

( inte rpersonal component, procedures enviro nment / process component, and te chnical / pr ofessional component ) to menghasil right quality service. Indeed there are basically 3 (three) main provisions in seeing the high and low quality of public service according to Morgan and Murgatroyd, namely the high and low quality of public services need to be considered a balance between:

a) The interpersonal part that carries out ( Inter Personal Component );

b) Part of the process and environment that influence ( Process and Environment );

c) Professional and technical parts used (Professional and Technical).

\subsection{Quality of Public Services}

Quality is a dynamic condition associated with products, services, people, processes and environments that meet or exceed expectations. Public service organizations have a characteristic of public accountability, where every citizen has the right to evaluate the quality of the service they receive. It is very difficult to assess the quality of a service without considering the role of the community as the recipient of the service and the service implementing apparatus. Ev aluasi coming from users of services, is an element of the first in the analysis of the quality of public services. The second element in analysis is the ease with which a service is recognized either before the process or after the service has been provided. Aim_public service is basically satisfying the community. To achieve that satisfaction, the quality of service is demanded, which is reflected in :

a) Transparency, which is a service that is open, easy and can be accessed by all parties who need and are provided adequately and easily understood.

b) Accountability, the waiter who accounted for in accordance with the provisions of the legislation.

c) Conditional, namely services that are in accordance with the conditions and capabilities of service providers and recipients while adhering to the principles of efficiency and effectiveness.

d) Participatory, namely services that can encourage community participation in managing public 
by taking into account the aspirations, needs, and expectations of the community.

e) Equality of rights, namely services that do not discriminate in terms of any aspect especially ethnicity, race, religion, class, social status, and so on.

f) Balance of rights and obligations, namely services that take into account aspects of justice between the giver and recipient of public services.

If related to public administration, service is the quality of service of bureaucrats to society. The word quality has many different and varied definitions ranging from the conventional to the more strategic. Conventional definitions of quality usually describe the direct characteristics of a product, such as :

a) Performance ( performance),

b) Reliability ( reliability ),

c) Easy to use ( easy of use ),

d) Aesthetics ( esthetics ).

\subsection{Compliance with statutory regulations}

Soerjono Soekanto argues that legal awareness is the values inherent in people about existing laws or expected laws. Ja in basically every human being has a sense of fairness, and the principle to mindless laws lies within every human being. There are opinions that state that high legal awareness causes citizens to comply with applicable regulations. Conversely, if legal awareness is very weak, the degree of unity of the law is also low. The indicators of legal awareness according

to

B. Kutschincky are:

a) Knowledge of legal regulations ( law awareness );

b) Knowledge of the contents of legal regulations ( law acquaintance );

c) Attitudes towards legal regulations (legal attitude );

d) Patterns of legal behavior ( law behavior ).

The indicators mentioned above indicate at a certain level of legal awareness ranging from the lowest to the highest. If indicators of legal awareness, namely knowledge about the law, knowledge about the contents of the law, attitudes toward the law and patterns of legal behavior are connected with legal compliance, then the following understanding will be obtained:

a) Knowledge of legal regulations does not affect compliance with regulations;

b) Knowledge of the contents of legal regulations greatly influences the attitude towards a regulation, but likes to determine exactly what degree of compliance is achieved with that knowledge;

c) Attitudes towards the tendency of regulations affect the level of legal compliance ;

d) The pattern of legal behavior greatly affects legal compliance, which behavior in accordance with the law is one of the characteristics or criteria for the existence of compliance or high enough legal compliance.

Research on compliance with the implementation of Law Number 25 of 2009 concerning Public Services has been carried out by the Indonesian Ombudsman since 2013 with the object of research of the State Ministries, Government Agencies, and local Governments both Provinces, Regencies and Cities, specifically for direct licensing services to community groups / individuals / agencies. Researchor survey tert ebut categoriz e the assessment based on the acquisition value of each Government of the Region. First, the red zone (score 0-50): reflects low compliance from public service providers to the implementation of Law Number 25 of 2009 concerning Public Service; second, the yellow zone (score 51-80): describes moderate compliance; and third, the green zone (score 81-100): illustrates high compliance.Pursuant to Article 15 and Chapter V of Law Number 25 Year 2009 concerning Public Services, Public Service Delivery must fulfill 10 elements regarding the implementation of the public service itself, which consists of: 
a) Service Standards The service component components referred to at least include: legal basis, requirements, system mechanism and procedures, duration of settlement, cost / tariff, service products, facilities, infrastructure, or facilities, implementing competencies, internal supervision, handling complaints , suggestions and input, number of implementers, service guarantees carried out in accordance with service standards, service security and service guarantees in the form of a commitment to provide a sense of security free from danger and risk of doubt, and evaluation of the performance of the implementer.

b) Notice of Service

c) The stem cells Information Public Service The series of events that include the storage and management of information and mechanisms for delivering information from the organizers of the public service to the community and vice versa in the form of oral, Latin inscription, written in letters braille, language picture, and / or language locally, and served manually or electronic.

d) Management of Facilities, Infrastructure, and / or Public Service Facilities.

e) Special Services Services with special treatment to certain members of the community include people with disabilities, elderly, pregnant women, children affected by natural disasters, without additional costs.

f) Costs / Tariffs for Public Services

g) Implementing Behavior in Services

h) Supervision of Service Delivery

i) Complaint Management

j) Performance assessment.

\section{Conclusion}

Therefore the Public Service Mall (MPP) is supposed to be a solution for new public services in Sumedang Regency by cutting the bureaucracy which has been considered an obstacle in the process of public service, rather than becoming a new problem in public service based on the non-optimal process of public service. Mall Public Service must meet the principles or the initial conception of public services that promote: Performance (performance),

Reliability (reliability), easy to

use ( easy of use ), Aesthetics ( esthetics) with based on the legal standing of which clearly do not get a good program. This in the process of public service only refers to KemenPan number 31 of 2019 but it must be strengthened with the issuance of a correct Regent Regulation ( Perbup ) governing it so that a good concept, a lot of processes must be evaluated, is strengthened with a clear legal umbrella from regional government by issuing the PERDUP. Because the quality of public services is a benchmark or indicator of government performance processes that are visible and can be assessed by the public, thus if the public service process is good, then automatically the least performance of the government can be said to be good. So the Public Service Mall needs a little evaluation for the sake of a good public service process towards the concept of good government.

\section{References}

Daviddow, William H. \& Bro Uttal. (1989). Total Customer Service. New York: Harper \& Row Publisher.

Fitzsimmons, James A and Mona J. Fitzsimmons. (2001). Service Management: Operations, Strategy, and Information Technology. Third Edition. Singapore: McGraw-Hill Book Co.

Gasperz, Vincent. (1997). Manajemen Kualitas Dalam Industri Jasa. Jakarta: PT. GramediaPustaka.

Kotler, Philip. (2004). Manajeman Pemasaran. Jakarta: PT Indeks.

Morgan and Murgatroyd. (1994). Total Quality Management in the Public Sector: An international perspective. Philadelphia: Open University Press. 
Journal Sampurasun : Interdisciplinary Studies for Cultural Heritage

Vol. VI, Number 01, June 2020

Osborne, David dan Gaebler, Ted. (1995). Mewirausahakan Birokrasi. Jakarta: PPM.

Ratminto, Atik Septi Winarsih, (2006). Manajemen Pelayanan: Pengembangan Modal Konseptual, Penerapan Citizen's Charter danStandarPelayanan Minimal. Yogyakarta: PustakaPelajar.

Shafrudin, Hadi. (2014). "AnalisisIndeksKepuasanMasyarakat (IKM) di RSUD Jendral Ahmad Yani Kota Metro". Skripsi. Bandar Lampung; FISIP UNILA.

Sinambela, Lijan P. Rochadi, Sigit. Ghazali, Rusman. Muksin, Akhmad.

Setiabudi, Didit. Bima, Djohan, danSyaifudin. (2006). Reformasi PelayananPublik: Teori, Kebijakan, dan Implementasi. Jakarta: BumiAksara.

Soekanto, Soerjono. (1982). Kesadaran Hukum Dan Kepatuhan Hukum. Jakarta: CV Rajawali.

Tjiptono, Fandy. (1997). Prinsip-prinsip Total Quality (TQS). Yogyakarta: Penerbit ANDI.

Trilestari, EndangWirjatmi. (2004). "Model Kinerja Pelayanan Publik dengan Pendekatan Systems Thinkinks and System Dinamics". Disertasi. Depok: FISIP UI

Undang-Undang Nomor 25 Tahun 2009 tentang Pelayanan Publik Peraturan Pemerintah Nomor 96 Tahun 2012 tentang Pelaksanaan Undang Undang Nomor 25 Tahun 2009 tentang Pelayanan Publik Peraturan Menteri Pendagunaan Aparatur Negara dan Reformasi Birokrasi Nomor 38 Tahun 2012 tentang Pedoman Penilaian Kinerja Unit PelayananPublik. 